\title{
Ammonia Triborane: A Promising New Candidate for Amineborane-Based Chemical Hydrogen Storage
}

\author{
Chang Won Yoon and Larry G. Sneddon* \\ Department of Chemistry, University of Pennsylvania, Philadelphia, Pennsylvania 19104-6323
}

Received June 26, 2006; E-mail: Isneddon@sas.upenn.edu

Because of their high hydrogen densities, boron based compounds, including especially sodium borohydride $\left(\mathrm{NaBH}_{4}\right)^{1}$ and ammonia borane $\left(\mathrm{NH}_{3} \mathrm{BH}_{3}\right),{ }^{2}$ are now being intensely investigated as chemical hydrogen storage materials that can release hydrogen by hydrolytic processes (eqs 1-2).

$$
\begin{aligned}
& \mathrm{NaBH}_{4}(\mathrm{~s})+2 \mathrm{H}_{2} \mathrm{O}(\mathrm{l}) \rightarrow \mathrm{Na}^{+}(\mathrm{aq})+\mathrm{BO}_{2}{ }^{-}(\mathrm{aq})+4 \mathrm{H}_{2}(\mathrm{~g})(1) \\
& \mathrm{NH}_{3} \mathrm{BH}_{3}(\mathrm{~s})+2 \mathrm{H}_{2} \mathrm{O}(\mathrm{l}) \rightarrow \mathrm{NH}_{4}{ }^{+}(\mathrm{aq})+\mathrm{BO}_{2}{ }^{-}(\mathrm{aq})+3 \mathrm{H}_{2}(\mathrm{~g})
\end{aligned}
$$

The high hydrogen release capacity that could potentially be achieved by ammonia triborane, $\mathrm{NH}_{3} \mathrm{~B}_{3} \mathrm{H}_{7}$, (1) oxidative-hydrolysis (eq 3 ) should likewise make it an attractive candidate for chemical hydrogen storage. But, owing to the lack of a suitable method for its efficient synthesis, there have been no previous explorations of the chemical hydrogen storage properties of this compound. We

$$
\begin{aligned}
& \mathrm{NH}_{3} \mathrm{~B}_{3} \mathrm{H}_{7}(\mathrm{~s})+6 \mathrm{H}_{2} \mathrm{O}(\mathrm{l}) \rightarrow \\
& \mathrm{NH}_{4}{ }^{+}(\mathrm{aq})+3 \mathrm{BO}_{2}{ }^{-}(\mathrm{aq})+2 \mathrm{H}^{+}(\mathrm{aq})+8 \mathrm{H}_{2}(\mathrm{~g})
\end{aligned}
$$

report here both a convenient and safe method for the synthesis of ammonia triborane and our initial studies of its hydrolytic hydrogenrelease properties that indicate it is a promising new material for chemical hydrogen storage applications.

Ammonia triborane was first synthesized by $\mathrm{Kodama}^{3}$ via the cleavage reaction of tetraborane, $\mathrm{B}_{4} \mathrm{H}_{10}$, with ethers to initially form $\mathrm{LB}_{3} \mathrm{H}_{7}\left(\mathrm{~L}=\right.$ tetrahydrofuran or tetrahydropyran) adducts (plus $\mathrm{B}_{2} \mathrm{H}_{6}$ ) that, following displacement of the ethers by reaction with anhydrous ammonia, then produced $\mathrm{NH}_{3} \mathrm{~B}_{3} \mathrm{H}_{7}$. Unfortunately, tetraborane is a volatile unstable compound that is explosive in air, and, as a result, any large-scale synthesis based on its use is not feasible.

Binder ${ }^{4}$ previously reported that $\mathrm{I}_{2}$ oxidation of $\mathrm{Me}_{4} \mathrm{~N}^{+} \mathrm{B}_{3} \mathrm{H}_{8}{ }^{-}$ in noncoordinating solvents (e.g., $\mathrm{CH}_{2} \mathrm{Cl}_{2}$ ) yielded the $\mathrm{B}_{3} \mathrm{H}_{7}$-dimer, $\mathrm{B}_{6} \mathrm{H}_{14}$. We have now found that iodine oxidation (with slow warming from -70 to $20{ }^{\circ} \mathrm{C}$ ) of the air stable $\mathrm{Bu}_{4} \mathrm{~N}^{+} \mathrm{B}_{3} \mathrm{H}_{8}{ }^{-}$salt in glyme (1,2-dimethoxyethane) (eq 4) allows the efficient preparation of solutions of the (glyme) $\mathrm{B}_{3} \mathrm{H}_{7}$ adduct. Direct treatment (eq 5) of these (glyme) $\mathrm{B}_{3} \mathrm{H}_{7}$ solutions with anhydrous ammonia then yields pure $\mathrm{NH}_{3} \mathrm{~B}_{3} \mathrm{H}_{7}$ as a colorless crystalline solid in $>80 \%$ yields (based on $\mathrm{Bu}_{4} \mathrm{~N}^{+} \mathrm{B}_{3} \mathrm{H}_{8}{ }^{-}$). Since the $\mathrm{Bu}_{4} \mathrm{~N}^{+} \mathrm{B}_{3} \mathrm{H}_{8}{ }^{-}$salt can itself be readily prepared ${ }^{5}$ by iodine oxidation of $\mathrm{BH}_{4}{ }^{-}$, the large-scale, safe synthesis of $\mathrm{NH}_{3} \mathrm{~B}_{3} \mathrm{H}_{7}$ is now possible.

$$
\begin{aligned}
\mathrm{Bu}_{4} \mathrm{~N}^{+} \mathrm{B}_{3} \mathrm{H}_{8}{ }^{-}+0.5 \mathrm{I}_{2}+ & \text { glyme } \rightarrow \\
(\text { glyme }) \mathrm{B}_{3} \mathrm{H}_{7}+\mathrm{Bu}_{4} \mathrm{NI}+0.5 \mathrm{H}_{2} & \\
(\text { glyme }) \mathrm{B}_{3} \mathrm{H}_{7}+ & \mathrm{NH}_{3} \rightarrow \mathrm{NH}_{3} \mathrm{~B}_{3} \mathrm{H}_{7}+\text { glyme }
\end{aligned}
$$

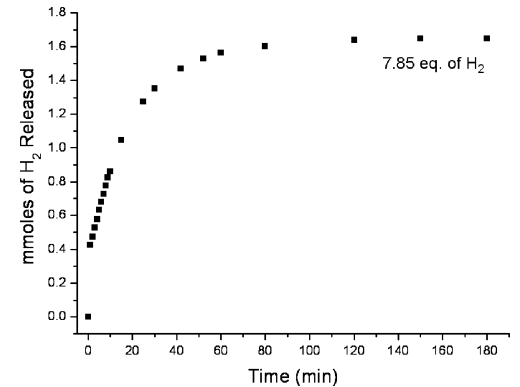

Figure 1. Acid-induced hydrogen release from ammonia triborane.

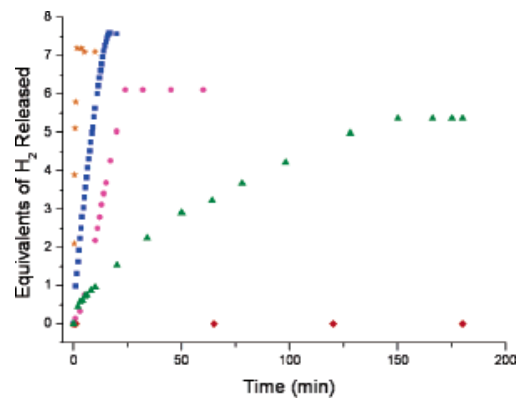

Figure 2. Metal-catalyzed hydrogen release from aqueous $(\sim 0.45 \mathrm{wt} \%)$ ammonia triborane solutions containing $(\star) \mathrm{RhCl}_{3}(6.9 \mathrm{~mol} \%)$; (口) $5 \mathrm{wt}$ $\%-\mathrm{Rh} / \mathrm{Al}_{2} \mathrm{O}_{3}(7.0 \mathrm{~mol} \%-\mathrm{Rh}) ;(\bullet)[\mathrm{Rh}(\mathrm{COD})(\mathrm{Cl})]_{2}(7.2 \mathrm{~mol} \%) ;(\boldsymbol{\Delta}) 5 \mathrm{wt}$ $\%-\mathrm{Rh}^{-} \mathrm{Al}_{2} \mathrm{O}_{3}(1.4 \mathrm{~mol} \%-\mathrm{Rh}) ;(\diamond)$ no catalyst.

1 is significantly more soluble in water than $\mathrm{NH}_{3} \mathrm{BH}_{3}$ (26 wt $\%$, , with $\mathrm{NH}_{3} \mathrm{~B}_{3} \mathrm{H}_{7}$ solutions of at least $33 \mathrm{wt} \%$ being attained. Also, unlike aqueous $\mathrm{NaBH}_{4}$, which is stable only in strongly alkaline solutions, ${ }^{1 \mathrm{~b}, \mathrm{c}}$ aqueous $\mathrm{NH}_{3} \mathrm{~B}_{3} \mathrm{H}_{7}$ solutions are quite stable at $\mathrm{pH} 7.5$ in air as evidenced by ${ }^{11} \mathrm{~B}$ NMR studies that showed a $25 \mathrm{wt} \%$ solution remained unchanged over 4 days.

Efficient hydrogen release from aqueous solutions of $\mathbf{1}$ was obtained upon the addition of either acids or appropriate metalcatalysts. As shown in Figure 1, quantitative measurements of hydrogen release using a gas buret showed that when an excess of aqueous $\mathrm{HCl}(1 \mathrm{~mL}$ of $12.1 \mathrm{M} \mathrm{HCl})$ was added to $12 \mathrm{mg}(0.21$ $\mathrm{mmol})$ of $\mathbf{1}$, a near theoretical value of 7.85 equiv $(1.65 \mathrm{mmol})$ of $\mathrm{H}_{2}$ was evolved over $\sim 1 \mathrm{~h}$.

More rapid hydrogen release was achieved using metals to catalyze the hydrolysis reaction. Hydrogen release from $\mathrm{NaBH}_{4}$ and $\mathrm{NH}_{3} \mathrm{BH}_{3}$ has previously been attained by metal-catalyzed hydrolysis, with $\mathrm{Ru}$-catalysts ${ }^{1}$ for $\mathrm{NaBH}_{4}$ and Pt-catalysts ${ }^{2}$ for $\mathrm{NH}_{3} \mathrm{BH}_{3}$ exhibiting the highest reactivities. We have now screened a variety of potential catalysts for ammonia triborane hydrolysis and found high activities for the rhodium based systems, $\mathrm{Rh}(0)$ supported on alumina, $[\mathrm{Rh}(\mathrm{COD})(\mu-\mathrm{Cl})]_{2}(\mathrm{COD}=1,5$-cyclooctadiene $)$, and $\mathrm{RhCl}_{3}$ (Figure 2). With high catalyst loadings of $\mathrm{RhCl}_{3}, \sim 7$ equiv of hydrogen were released in only $1.5 \mathrm{~min}$ at room temperature. Although they are unchanged upon initially dissolving in water,

10.1021/ja064526g CCC: $\$ 33.50$ @ 2006 American Chemical Society 


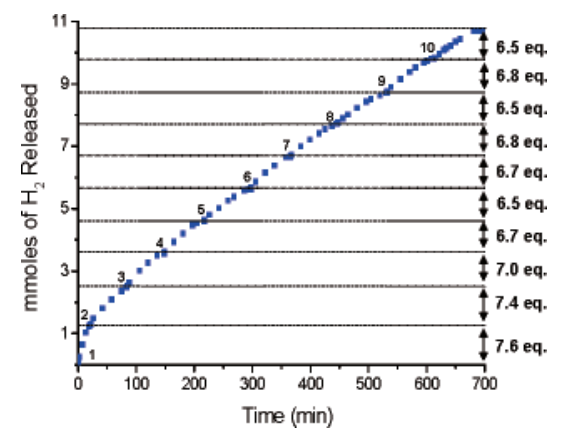

Figure 3. Hydrogen evolution following repeated additions of ammonia triborane to an aqueous solution containing $5 \mathrm{wt} \%-\mathrm{Rh} / \mathrm{Al}_{2} \mathrm{O}_{3}$.

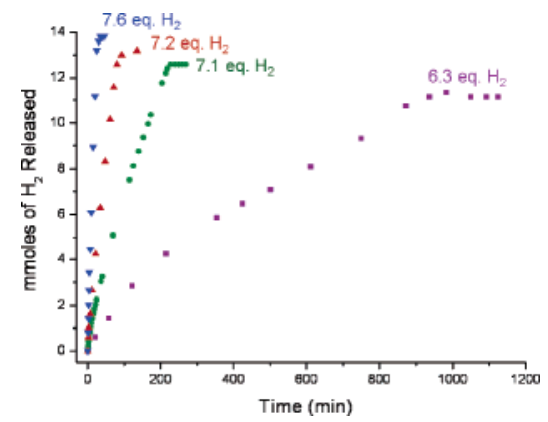

Figure 4. Hydrogen release at different temperatures $(\mathbf{\nabla}, 50 ; \mathbf{\Lambda}, 35$; $\bullet$ $20 ; \boldsymbol{\square}, 0{ }^{\circ} \mathrm{C}$ ) versus time for $4.9 \mathrm{wt} \%$ aqueous solutions of ammonia triborane catalyzed by $5 \mathrm{wt} \%-\mathrm{Rh} / \mathrm{Al}_{2} \mathrm{O}_{3}(1.1 \mathrm{~mol} \%-\mathrm{Rh})$.

both the $[\mathrm{Rh}(\mathrm{COD})(\mu-\mathrm{Cl})]_{2}$ and $\mathrm{RhCl}_{3}$ appear to undergo reduction upon ammonia triborane addition suggesting that Rh clusters and/ or colloids may be the active catalytic species in these systems. ${ }^{6}$

The rhodium catalysts have also been found to have extended lifetimes. Thus, as indicated in Figure 3, hydrogen evolution measurements following periodic additions of $\sim 9 \mathrm{mg}(\sim 0.16 \mathrm{~mol})$ of solid ammonia triborane to a $2 \mathrm{~mL}$ aqueous borate-buffered $(\mathrm{pH}$ maintained between 7.2 and 8.0) solution containing $1.3 \mathrm{mg}(0.012$ mmol $\mathrm{Rh}$ ) of $5 \mathrm{wt} \%-\mathrm{Rh} / \mathrm{Al}_{2} \mathrm{O}_{3}$ showed little change in the hydrogen release rates over 10 cycles.

An Arrhenius plot of the initial rate data (Figure 4) for hydrogen release from a 5 wt $\%-\mathrm{Rh} / \mathrm{Al}_{2} \mathrm{O}_{3}(1.1 \mathrm{~mol} \%-\mathrm{Rh})$ catalyzed reaction of a 4.9 wt $\%$ ammonia triborane solution at different temperatures yielded an activation energy of $13.4 \mathrm{kcal} / \mathrm{mol}$, which is in the range found for metal-catalyzed $\mathrm{NaBH}_{4}$ hydrolysis ( $\sim 9$ to $18 \mathrm{kcal} / \mathrm{mol}$, depending on the catalyst ${ }^{1}$ ).

Calculations of the standard heats of eqs 1-3 using standard enthalpies of formation, ${ }^{7}$ indicate that hydrogen release from $\mathrm{NH}_{3} \mathrm{~B}_{3} \mathrm{H}_{7}$ is slightly more exothermic $\left(15.8 \mathrm{kcal} / \mathrm{mol}-\mathrm{H}_{2}\right)$ than that from either $\mathrm{NaBH}_{4}\left(14.9 \mathrm{kcal} / \mathrm{mol}-\mathrm{H}_{2}\right)$ or $\mathrm{NH}_{3} \mathrm{BH}_{3}(12.7 \mathrm{kcal} / \mathrm{mol}-$ $\mathrm{H}_{2}$ ), but is much less than the hydrolytic reactions of metal hydrides (e.g., $\mathrm{LiAlH}_{4}, \sim 30 \mathrm{kcal} / \mathrm{mol}^{-\mathrm{H}_{2}}$ ). ${ }^{8}$

As illustrated in Figure 5, the hydrolysis reaction of a $22.7 \mathrm{wt}$ $\%$ sample of aqueous ammonia triborane containing $0.30 \mathrm{~g}$ of $\mathrm{H}_{2} \mathrm{O}$, $0.10 \mathrm{~g}$ of $\mathrm{NH}_{3} \mathrm{~B}_{3} \mathrm{H}_{7}(1.8 \mathrm{mmol})$, and $0.04 \mathrm{~g}$ of $5 \mathrm{wt} \%-\mathrm{Rh} / \mathrm{Al}_{2} \mathrm{O}_{3}$ (0.02 mmol of Rh) produced $0.027 \mathrm{~g}\left(13.5 \mathrm{mmol}, 7.5\right.$ equiv) of $\mathrm{H}_{2}$ (measured by gas buret) over $3 \mathrm{~h}$ at $21^{\circ} \mathrm{C}$. This result corresponds to a production of $6.1 \mathrm{wt} \% \mathrm{H}_{2}$ based on materials [wt \% $=\mathrm{H}_{2^{-}}$ $\mathrm{wt} /\left(\mathrm{NH}_{3} \mathrm{~B}_{3} \mathrm{H}_{7}+\mathrm{H}_{2} \mathrm{O}+\mathrm{Rh} / \mathrm{Al}_{2} \mathrm{O}_{3}\right.$-wts $\left.)\right]$ and suggests that the DOE 2007 total-system target ${ }^{9}$ of $4.5 \mathrm{wt} \%$ for hydrogen release from a chemical hydrogen storage system might be attainable with this

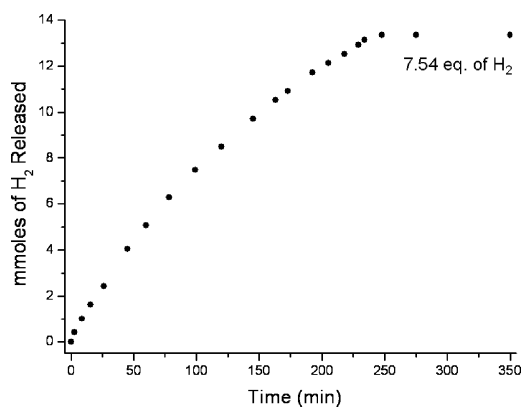

Figure 5. Rhodium ( 5 wt $\%-\mathrm{Rh} / \mathrm{Al}_{2} \mathrm{O}_{3}, 1.0 \mathrm{~mol} \%$ - $\mathrm{Rh}$ ) catalyzed $\mathrm{H}_{2}$ release from a 22.7-wt \% aqueous solution of ammonia triborane $(1.8 \mathrm{mmol})$ yielding $6.1 \mathrm{wt} \% \mathrm{H}_{2}$ [wt $\%=\mathrm{H}_{2}$-wt/ $\left(\mathrm{NH}_{3} \mathrm{~B}_{3} \mathrm{H}_{7}+\mathrm{H}_{2} \mathrm{O}+\mathrm{Rh} / \mathrm{Al}_{2} \mathrm{O}_{3}\right.$-wts)].

system. Under these concentrated conditions, ${ }^{11} \mathrm{~B}$ NMR studies show that the hydrolysis reaction yields condensed polyborates, which upon addition of water form mixtures of $\mathrm{B}(\mathrm{OH})_{3} / \mathrm{B}(\mathrm{OH})_{4}{ }^{-} .{ }^{10}$ Thus, the real utility of this process as a chemical hydrogen storage system will ultimately depend on the development of new "off-board" methods to regenerate ammonia triborane from these borates.

Acknowledgment. We thank the U.S. Department of Energy Center of Excellence for Chemical Hydrogen Storage for support. We also thank Dr. Goji Kodama for his helpful comments.

Supporting Information Available: Experimental procedures for the synthesis of $\mathrm{NH}_{3} \mathrm{~B}_{3} \mathrm{H}_{7}$ and the hydrogen release studies. This material is available free of charge via the Internet at http://pubs.acs.org.

\section{References}

(1) (a) Amendola, S. C.; Sharp-Goldman, S. L.; Janjua, M. S.; Kelly, M. T.; Petillo, P. J.; Binder, M. J. Power Sources 2000, 85, 186-189. (b) Amendola, S. C.; Sharp-Goldman, S. L.; Janjua, M. S.; Spencer, N. C.; Kelly, M. T.; Petillo, P. J.; Binder, M. Int. J. Hydrogen Energy 2000, 25, 969-975. (c) Dong, $\mathrm{H}$; Yang, $\mathrm{H}$; Ai, X ; Cha, C. Int. J. Hydrogen Energy 2003, 28, 1095-1100. (d) Jeong, S. U.; Kim, R. K.; Cho, E. A.; Kim H.-J.; Nam, S.-W.; Oh, I.-H.; Hong, S.-A.; Kim, S. H. J. Power Sources 2005, 144, 129-134. (e) Krishnan, P.; Yang, T.-H.; Lee, W.-Y.; Kim C.-S. J. Power Sources 2005, 143, 17-23. (f) Kojima, Y.; Suzuki, K.; Fukumoto, K.; Sasaki, M.; Yamamoto, T.; Kawai, Y.; Hayashi, H. Int. J. Hydrogen Energy 2002, 27, 1029-1034.

(2) (a) Chandra, M.; Xu, Q. J. Power Sources 2006, 156, 190-194 (b) Chandra, M.; Xu, Q. J. Power Sources 2006, 159, 855-860. (c) Kelly, H. C.; Marriott, V. B. Inorg. Chem. 1979, 18, 2875-2878. (d) T-Raissi, A. Proc. 2002 U.S. DOE Hydrogen Program Rev. 2002, 10; www1.eere.energy.gov/hydrogenandfuelcells/pdfs/32405b15.pdf.

(3) (a) Kodama, G.; Parry, R. W.; Carter, J. C. J. Am. Chem. Soc. 1959, 81 , 3534-3538. (b) Nordman, C. E.; Reimann, C. J. Am. Chem. Soc. 1959 81, 3538-3543.

(4) Brellochs, B.; Binder, H. Angew. Chem., Int. Ed. Engl. 1988, 27, 262263.

(5) (a) Nainan, K. C.; Ryschkewitsch, G. E. Inorg. Nucl. Chem. Lett. 1970 6, 765-766. (b) Ryschkewitsch, G. E.; Nainan, K. C. Inorg. Synth. 1974, $15,113-114$

(6) (a) Chen, Y.; Fulton, J. L.; Linehan, J. C.; Autrey, T. J. Am. Chem. Soc. 2005, 127, 3254-3255. (b) Chen, Y.; Fulton, J.; Linehan, J.; Autrey, T. Prepr. Symp.-Am. Chem. Soc., Div. Fuel Chem. 2004, 49, 972-973. (c) Schulz, J.; Roucoux, A.; Patin, H. Chem. Commun. 1999, 535-536.

(7) (a) CRC Handbook of Chemistry and Physics, 85th ed.; CRC Press: New York, 2004-2005. (b) A value of $-49 \mathrm{kcal} / \mathrm{mol}$ for the standard heat of formation of ammonia triborane was taken from Dunn Engineering, "Rocket Engine Specific Impulse Program" http://www.dunnspace.com/ isp.htm (page 8) (accessed June 2006).

(8) (a) Messer, C. E.; Fasolino, L. G.; Thalmayer, C. E. J. Am. Chem. Soc. 1955, 77, 4524-4526. (b) Davis, W. D.; Mason, L. S.; Stegeman, G. J. Am. Chem. Soc. 1949, 71, 2775-2781.

(9) U.S. DOE, "Hydrogen, Fuel Cells \& Infrastructure Technologies Program", http://www.eere.energy.gov/hydrogenandfuelcells/storage/pdfs/ (accessed June 2006).

(10) (a) Momii, R. K.; Nachtrieb, N. H. Inorg. Chem. 1967, 6, 1189-1192. (b) Smith, H. D., Jr.; Wiersema, R. J. Inorg. Chem. 1972, 11, 1152-1154. JA064526G 